\title{
A review of botanical characteristics, chemical composition, pharmacological activity and use of parsley
}

\author{
Milka Punoševac, Jelena Radović, Aleksandra Leković, \\ Tatjana Kundaković-Vasović*
}

University of Belgrade-Faculty of Pharmacy, Department of Pharmacognosy, 450 Vojvode Stepe, 11221 Belgrade, Serbia

*Corresponding author: Tatjana Kundaković-Vasović, e-mail: ktatjana@pharmacy.bg.ac.rs

\begin{abstract}
Parsley is a biennial aromatic plant from the Apiaceae family, which is characterized by an unbranched root, pinnately divided leaves, umbels and schizocarp. It contains essential oil in all parts, with phenylpropane and terpene compounds as main components. It is rich in flavonoids and other polyphenolic compounds, containing furanocoumarins, carotenoids, polyacetylenes, and its leaves are a source of vitamins and minerals. The chemical composition of parsley depends on a number of factors, so it differs not only in different parts and varieties of the plant, but also in different samples of the same parts of one variety. The most important parsley compounds are myristicin, apiol, 1-allyl-2,3,4,5-tetramethoxybenzene, $\beta$-phellandrene, 1,3,8-p-menthatriene, $\beta$-pinene, terpinolene, apiin, oxypeucedanin and falcarinol. Parsley has a long tradition of use in the treatment of urinary tract disorders, and modern in vitro and in vivo studies reveal numerous effects of various parsley preparations such as diuretic, antiurolithiasis, hypouricemic, hypolipidemic, hypoglycemic, hypotensive, antioxidant, anti-inflammatory and antiplatelet effect. Today, apart from its medical application, parsley is one of the most commonly used culinary herbs.
\end{abstract}

Key words: Petroselinum crispum, essential oil, flavonoids, antioxidants 


\section{Introduction}

Parsley (Petroselinum crispum (Mill.) Nym) is a biennial aromatic plant from the Apiaceae family. This medicinal herb has been widely used in the Mediterranean for more than 2000 years, firstly by Ancient Greeks in religious rites until Hippocrates introduced it as a diuretic. Parsley was brought to Central Europe by the Romans, and around 795 CE its cultivation in this area become obligatory by the law of Charles the Great. Today, in addition to its medical use, parsley is used as a spice around the world, mostly in omelets, salads, sauces, soups, for making herb butter but also as an accompaniment to various other dishes (1).

This paper will describe the botanical characteristics of parsley, some of which are common to all species of the Apiaceae family, as well as the chemical composition of parsley leaves, roots and fruits, including the composition of their essential oils, and variations in composition under the influence of different factors. Both in vitro and in vivo assays will be presented in order to prove the pharmacological effects of parsley fruits, roots and leaves, their various extracts, essential oils and isolated components. Toxic effects and studies of the mechanisms of action of active components will be also discussed. In addition, the use of parsley in different folk medicines, as well as the traditional and modern use, will be covered.

\section{Taxonomy}

The Umbelliflorae order includes seven families, and the most abundant is the Apiaceae family, which counts 275 genera and 2850 species growing around the world (2). Only in the Republic of Serbia, this family is represented with 53 genera and 138 species (3). This family is also commonly known as the Umbelliferae family, because of the characteristic inflorescences that look like a shield (umbella - shield) (4).

Petroselinum crispum (Mill.) Nym, parsley (syn. Petroselinum sativum Hoffm., Petroselinum hortense Hoffm., Apium crispum Mill., Apium petroselinum L.) is the only species of genus Petroselinum that grows in the Republic of Serbia (3). Parsley appears in three common cultivated varieties as P. crispum var. crispum - curly leaf parsley; P. crispum var. neapolitanum - flat leaf parsley; and P. crispum var. tuberosum - rooted parsley (5).

\section{Botanical description}

The parsley root is fusiform, up to $20 \mathrm{~cm}$ long, yellowish and almost fibreless, sweet to slightly astringent $(1,6,7)$. It is a biennial plant. A leaf rosette is developed in the first year while vertical, hollow stem with opposite branches is developed during the second year. The leaves are dark green and shiny. The basal ones are 2 or 3 time pinnately divided and the upper ones are sessile with linear shaped apical lobes. The flowers are small, actinomorphic, male or hermaphroditic, with white or yellowish corolla and barely developed calyx. It flowers from June to July, in the second year $(1,3,4)$. 
The characteristic fruit for all members of the Apiaceae family is an ovate, greenish and ribbed schizocarp, which breaks into two equal mericarps when ripe $(4,7)$. Each mericarp has a ventral, flat side and dorsal, convex side. Mericarp contains 5 main, elongated ribs ( 3 dorsal and 2 lateral) composed of mechanical tissue and between the main ribs, in the dents, there are secondary ribs. Secretory channels with essential oil are placed in the mesocarp of secondary ribs. Except essential oil, these channels contain simple coumarins and furanocoumarins which are responsible for characteristic smell and taste of parsley fruit $(3,4)$.

It is important to distinguish the aerial parts of the parsley from similar poisonous species of such as Aethusa cynapium ("fool's parsley") and Conium maculatum (hemlock). Both species are characterized by lighter-colored leaves, which leave an unpleasant odor after rubbing, and white corolla leaves, while hemlock has a stem with brown-red dots. Parsley root can also be substituted for the root of Pastinaca sativa (parsnip), but this species is edible and also used as a culinary spice (1).

\section{Habitat and cultivation}

Parsley originates from Southwestern Europe and Western Asia. Although parsley grows widely upon old walls and fields, it is cultivated around the world as a culinary spice $(1,3)$. Parsley is usually sown at the end of winter (in March or April), less often in autumn, on moist, light, humus soil. The leaves can be harvested in June, and the roots in October or November. Parsley can also be grown as a potted plant. Interestingly, it cannot be sown for more than one season in the same location due to auto-incompatibility (1). Despite being commonly known as an aromatic plant, in addition to essential oil, parsley contains numerous components of various pharmacological activities (6). The root (Petroselini radix), aerial parts (Petroselini herba) and fruit (Petroselini fructus) are used as herbal drugs. The essential oil of parsley (Petroselini aetheroleum) is derived from the fruit $(1,6,8)$. Parsley essential oil is used in the food industry as a flavoring agent for various foods (8).

\section{Chemical composition of parsley essential oil}

Parsley essential oil is obtained by steam distillation of parsley fruit (fresh, ripe and pulverized). Although the fruit contains most of the oil, it is also present in leaves and roots. Parsley essential oil is pale yellow or colorless (6). This essential oil is a mixture of different metabolites such as phenylpropanoids, monoterpenes, sesquiterpenes, alcohols, aldehydes, ketones and aromatic compounds (1,9). Parsley essential oil is best known for its use in food, pharmaceutical, cosmetic and chemical industries (10). The major components of essential oil from parsley leaf, herb, root and fruit are presented in Table I. 
Table I Major components of parsley leaf, herb, root and fruit essential oils.

Tabela I Glavne komponente etarskog ulja listova, herbe, korena i plodova peršuna.

\begin{tabular}{|c|c|c|c|c|c|}
\hline & art of the plant & $\begin{array}{c}\text { Leaf } \\
(1,5,7,9)\end{array}$ & $\begin{array}{l}\text { Herb } \\
(7,11)\end{array}$ & $\begin{array}{c}\text { Root } \\
(1,7,8)\end{array}$ & $\begin{array}{c}\text { Fruit } \\
(7,8,9)\end{array}$ \\
\hline \multirow{5}{*}{ 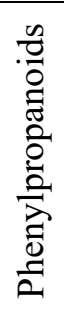 } & apiol & + & + & + & + \\
\hline & myristicin & + & + & + & + \\
\hline & elemicin & + & - & + & + \\
\hline & 1-allyl-2,3,4,5-tetramethoxybenzene & - & + & - & + \\
\hline & eugenol & - & - & - & + \\
\hline \multirow{15}{*}{ 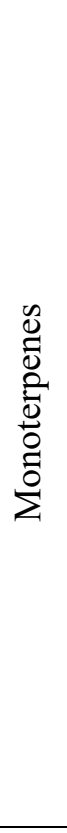 } & $\beta$-phellandrene & + & + & + & + \\
\hline & $p$-mentha-1,3,8-triene & + & + & - & - \\
\hline & 4-isopropenyl-1-methylbenzene & + & - & - & - \\
\hline & myrcene & + & + & - & + \\
\hline & $\alpha$-pinene & + & + & + & + \\
\hline & $\beta$-pinene & + & + & + & + \\
\hline & $\alpha$-phellandrene & + & + & - & - \\
\hline & p-cymene & + & - & - & + \\
\hline & terpinolene & + & + & + & - \\
\hline & $\alpha$-terpinene & + & - & - & - \\
\hline & myrtenyl acetate & + & - & - & - \\
\hline & limonene & + & + & + & + \\
\hline & $\alpha, p$ - dimethylstyrene & - & + & - & - \\
\hline & sabinene & + & - & - & + \\
\hline & $\gamma$-terpinene & + & - & - & + \\
\hline \multirow{12}{*}{ 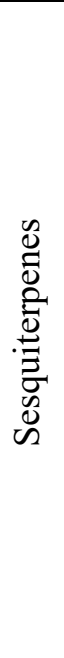 } & (E)- $\beta$-fernesene & + & & \multirow{9}{*}{-} & \multirow{11}{*}{-} \\
\hline & germacrene D & + & & & \\
\hline & angelic acid esters & + & & & \\
\hline & $\alpha$-copaene & + & & & \\
\hline & $\alpha$ and $\beta$-cubebene & + & & & \\
\hline & $\gamma$-elemene & + & & & \\
\hline & $\alpha$-humulene & + & & & \\
\hline & $\gamma$-amorphene & + & & & \\
\hline & $\alpha$-, $\gamma$ - and $\delta$-cadinene & + & & & \\
\hline & germacrene A & - & & + & \\
\hline & $\beta$ - bisabolene & + & & + & \\
\hline & carotol & - & & - & + \\
\hline
\end{tabular}




\section{Leaf essential oil}

Parsley leaf contains $0.02-0.9 \%$ of essential oil with phenylpropanoids (up to $80 \%$ ) and monoterpenes as main compounds. Sesquiterpenes are present in smaller amounts, up to $4 \%$. Phenylpropanoids and monoterpenes contribute to the odor (1). Odorcontributing substances, found in small amounts, are also: methyl-2-methylbutanoate, oct-1-en-3-one, $\quad(Z)$-1,5-octadiene-3-one, 2-(p-tolyl)propan-2-ol, 2-isopropyl-3methoxypyrazine, 2-sec-butyl-3-methoxypyrazine, $(Z)$-6-decenal, $(E, E)$-2,4-decadienal, myrcene, linalool, citronellol and $\beta$-ionone (1). Other substances found in parsley essential oil are: aldehydes (phenylacetaldehyde, hexanal, benzaldehyde), aromatic compounds (toluene, $m$ - and/or $p$-xylene), ethers (2-pentylfuran), alcohols ((Z)-hex-3-en1-ol) and ketones (cryptone) (9). A hay-like odor develops through leaf drying processes as a result of 3-methyl-2,4-nonanedione forming. Parsley leaf taste is similar to cabbage, due to presence of dimethyl sulfide, methylpropane and 2- and 3-methylbutanal (1).

Essential oils of different chemical composition can be the consequence of seasonal variation (plant and harvest time), stage of growth (,age“ of parsley) and geographic location. As a consequence of seasonal variation, higher concentrations of apiol were detected in parsley planted in December and harvested in April than in parsley planted in September and harvested in January. The aging of flat leaf parsley caused a decrease in the concentration of $\beta$-phellandrene $(58.3 \% \rightarrow 0 \%)$ and myristicin $(12 \% \rightarrow 0 \%)$, and an increase in the concentration of $1,3,8-p$-menthatriene $(0.4 \% \rightarrow 79.9 \%)$ (5). The amount of individual components varies in different parts of the plant and varieties (9). For example, the variable chemical composition of parsley essential oil was confirmed by testing the composition of essential oil obtained by hydrodistillation from 4 commercial samples -2 samples of flat leaf parsley and 2 samples of curly leaf parsley. Apiol (52.9\% and 33.0\%) and $\beta$-phellandrene (10.0 and 17.0\%) were the two most abundant compounds in flat leaf samples, while the third most represented compound in first sample was $1,3,8-p$-menthatriene with $23.4 \%$ (1.5\% in the second sample) and $p$-cymene in the second sample with $17.3 \%(0.3 \%$ in the first sample). Myristicin was not detected in flat leaf parsley, but in curly leaf samples it was the most represented compound (39.4\% and $43.2 \%)$ followed by $\beta$-phellandrene $(31.7 \%$ and $35.0 \%)$ and $1,3,8-$ $p$-menthatriene (14.9\% and $7.9 \%)(5)$.

Due to large differences in the content of individual components, parsley leaf essential oils can be divided into three classes: a myristicin-rich oil (most of the samples that originated from curly leaf); a 1,3,8-p-menthatriene-rich oil (most of the samples that originated from flat leaf); and an apiole-rich oil (can be found in both sample varieties). All three of the classes contain high levels of $\beta$-phellandrene (5).

\section{Root essential oil}

P. crispum ssp. foliosum and P. crispum ssp. tuberosum roots have different amounts of essential oil and a slightly different composition. P. crispum ssp. tuberosum roots consist of 0.1 to $0.3 \%$ of essential oil. The quantity of essential oil in P. crispum ssp. foliosum roots is $0.20-0.75 \%$ (1). If oil is acquired by using hydrodistillation, the 
main components are phenylpropanoids and monoterpenes, but if the oil is obtained by using diethyl ether, the main compounds are polyacetylenes: falcarinol (30\%) and falcarinidiol $(9 \%)(1,8)$.

\section{Fruit essential oil}

Parsley fruit contains 1-6\% of essential oil; P. crispum ssp. tuberosum has $1-4 \%$ and $P$. crispum ssp. foliosum $2-6 \%$ of essential oil. Phenylpropanoid contents differ between various fruit types: $P$. crispum ssp. tuberosum fruit contains the highest levels of apiole; P. crispum ssp. foliosum contains the highest levels of myrsticin and P. crispum ssp. foliosum contains similar levels of apiol and myristicin and high level of 1-allyl2,3,4,5-tetramethoxybenzene (8). Ethanol fruit extract contains sesquiterpenes crispane and crispanone (9).

\section{Other constituents of parsley leaf, root and fruit}

Flavonoids are major ingredients of parsley, followed by polyacetylenes $(9,12)$. Parsley contains several important nutrients such as vitamin $\mathrm{C}, \mathrm{A}$ and $\mathrm{B}$ vitamin complex, vitamin $\mathrm{K}$, tocopherols, ergosterol (precursor of vitamin D). It is also rich in minerals (Fe, $\mathrm{Zn}, \mathrm{Ca}, \mathrm{Mg}, \mathrm{Na}, \mathrm{K}, \mathrm{P}$ ), fatty acids (linolenic and palmitic acid), carotenoids and furanocoumarins $(13,14,15,16)$. Major furanocoumarins and flavonoids are presented in Table II.

Table II Major flavonoids and furanocoumarins in parsley leaf, root and fruit.

Tabela II Glavni flavonoidi i furanokumarini u listu, korenu i plodu peršuna.

\begin{tabular}{lccc}
\hline & Parsley leaf & Parsley roots & Parsley fruit \\
& $(1,13)$ & $(1,13)$ & $(7,8)$ \\
\hline Total flavonoid content & $1.9-6.6 \%$ & $0.2-1.6 \%$ & $2 \%$ \\
Apiin & + & + & + \\
Total furanocoumarins content & $0.2 \%$ & $0.1 \%$ & $/$ \\
Oxypeucedanin & + & + & + \\
Xanthotoxin & + & + & + \\
Bergaptene & + & + & + \\
Psoralen & + & - & + \\
Isopimpinellin & + & + & + \\
Imperatorin & + & + & - \\
Angelicin & + & + & - \\
Trioxsalen & + & + & + \\
\hline
\end{tabular}




\section{Parsley leaf}

Flavonoids are the predominant compounds of parsley leaf. Besides apiin, which is also found in roots and fruit, other flavonoid compounds found only in parsley leaf are glycosides such as luteolin 7-apiosylglucoside, apigenin 7-glucoside, isorhamnetin 3,7diglucoside and 6"-acetylapiin and aglycones quercetin and kaempferol $(1,9,13,15)$. In parsley aqueous extract naringin, naringenin, hesperidin, rutin and also glycosides of luteolin and apigenin with arabinose, rhamnose and glucose are identified, along with glycosides of isorhamnetin, kaempferol and chrysoeriol $(9,15,17)$.

Parsley leaves also contain $0.2 \%$ of furanocoumarins (oxypeucetanin, bergaptene, psoralen and others) $(1,13)$.

Vitamin $\mathrm{C}$ can be found in fresh parsley leaf in quantities between 0.12-0.4 \% (1). Cultivated flat leaf form of $P$. crispum ssp. foliosum contains the highest content of ascorbic acid, followed by $\alpha$ - and $\gamma$-tocopherol. The content of $\gamma$-tocopherol and total tocopherols is the highest in flat leaf parsley form. Variations in $\alpha$-tocopherol (main form of vitamin E) content can be significant in relation to antioxidative activity of this plant (13). Parsley leaf also contains carbohydrates such as apiose, which are mostly part of flavonoids glycosides (9). Sucrose, glucose, rhamnose, mannose, arabinose and mannitol were identified in parsley leaf aqueous extract (15). Carotenoids, $\beta$-carotene, lutein, violaxanthin and neoxanthin are also found $(9,13)$. Falcarinol, falcarindiol, falcarinone and falcarinolone are identified among polyacetylenes (12).

\section{Parsley roots}

Furanocoumarins (oxypeucetanin, bergaptene, xanthotoxin and others) are the main constituents of roots $(1,13)$. Phtalides such as $(Z)$-ligustilide, senkyunolide and butylphtalide are also present in lower concentrations in parsley roots and they are shown to contribute to odor $(1,8)$. The majority of polyacetylenes are detected in parsley root: falcarinol, falcarindiol, falcarinone and falcarinolone $(1,7,8)$.

\section{Parsley fruit}

The main components of parsley fruit, besides furanocoumarins, are fatty oils in the content of $25 \%$ (8). The main fatty acid is petroselinic acid (60-80\%) in the form of glycerides (7). Carbohydrate apiose (as a part of flavonoid glycosides) is also detected (9).

\section{Pharmacological activities}

In addition to the well-known diuretic and antispasmodic effect, the active ingredients of parsley are responsible for a very wide range of positive effects: hepatoprotective, antidiabetic, analgesic effects. Anti-inflammatory, antianemic, antihyperlipidemic, antitumor, antihypertensive, anticoagulant and immunosuppressive effects are more related to the active components of parsley leaves (13). Various preparations of parsley also have antimicrobial, hypouricemic, antioxidant, and estrogenic effects (18). 


\section{Diuretic effect}

It has been proven in vivo, on mice and rats, that parsley fruit has a diuretic effect, due to the irritating effect of the essential oil and flavonoids on renal parenchyma $(1,6,8)$. Moreover, in vivo experiments show that aqueous extract of parsley fruit increases urine volume and water intake, and consequently increases urine flow while inhibiting kidney $\mathrm{Na}^{+} / \mathrm{K}^{+}$-ATPase activity, with stronger inhibition observed against cortex ATPase $(94.7 \%$ compared to 55\% inhibition of medullary ATPase). This inhibition results in decreased reabsorption of $\mathrm{K}^{+}$and $\mathrm{Na}^{+}$from the tubular lumen; water follows these ions, which leads to a diuretic effect (19). Additionally, flavonoids, such as quercetin, kaempferol and naringenin found in parsley leaves, have an antagonistic activity at adenosine A1 receptors, which leads to a diuretic effect. It should be noted that conventional diuretics often cause hypokalemia, while parsley, as a rich source of potassium, does not express this side effect $(14,20)$. The parsley root also has a diuretic effect, but it is less intense than the effect of the fruit (8).

\section{Spasmolytic effect}

Preparations of the fruit, root and herb of parsley have a spasmolytic effect. Essential oil constituents apiol and myristicin act primarily on the uterus (8). Ethanol extract of $P$. crispum fruit reduces $\mathrm{KCl}$ and $\mathrm{CaCl}_{2}$-induced contractions of isolated rat ileum by blocking voltage-dependent $\mathrm{Ca}^{2+}$ channels. Aqueous and ethanol extracts of the aerial parts also show a spasmolytic effect on contracted isolated rat ileum induced both spontaneously and by acetylcholine. Both these effects are dose-dependent $(21,22)$. Parsley root also acts as a mild antispasmodic (6).

\section{Anti-urolithiasis effect}

The anti-urolithiasis effect of parsley has been the subject of several in vivo studies on rats with induced urolithiasis and similar results were obtained. In ethylene glycol (EG) - induced urolithiasis, the aqueous extract of $P$. crispum aerial parts and roots reduced serum urea and uric acid levels and increased serum $\mathrm{Mg}^{2+}$ levels. In rats fed with EG, the aqueous extract of the roots and aerial parts of $P$. crispum led to a decrease in the number of calcium oxalate deposits (16). In EG and $\mathrm{NH}_{4} \mathrm{Cl}$-induced urolithiasis on male albino rats, ethanol extract of $P$. crispum fruit contributed to a decrease in urinary $\mathrm{Ca}^{2+}$, protein excretion and urine $\mathrm{pH}$, and a decrease in the number, size and precipitation of calcium oxalate crystals. Some studies suggest that the potential mechanisms by which parsley exerts its anti-urolithiasis effect may be related to the high chlorophyll content (inhibits the calcium oxalate dehydrate formation, which consequently prevents the occurrence of kidney stones) and $\mathrm{Mg}^{2+}$ content (binds intestinal oxalates and reduces their availability for calcium to form calcium oxalate stones) $(14,16)$. Active compounds with antioxidant activity (rutin, quercetin, hyperoside and diosmin) are probably the most responsible for the anti-urolithiasis effect (16). 


\section{Hypouricemic effect}

In an in vivo investigation performed on mice with oxonate-induced hyperuricemia, the effect of aqueous parsley leaf extract was demonstrated by various mechanisms. The use of this extract leads to a significant reduction of uric acid levels, blood urea nitrogen (BUN), aspartate transaminase (AST) and alanine transaminase (ALT), and a reduction of the activity of serum and hepatic xanthine oxidase (an enzyme responsible for uric acid synthesis). Also, it acts against oxidative stress that occurs in hyperuricemic mice by: lowering the level of interleukin 1 beta (IL-1 $\beta$ ) and tumor necrosis factor alpha (TNF- $\alpha$ ) (inflammatory cytokines) and increasing the level of interleukin 10 (IL-10) in the serum (anti-inflammatory cytokines), lowering the level of malondialdehyde (MDA) that causes tissue damage and enhancing antioxidant capacity by increasing catalase enzyme levels, glutathione peroxidase, as well as reduced glutathione levels. In addition, it promotes the regeneration of normal kidney structure (23).

\section{Antioxidant effect}

Phenolic compounds and especially flavonoids can be H-donors to free radicals and can prevent cell damage and inhibit numerous biochemical processes in the human body, thus having a positive effect on chronic degenerative and neurodegenerative changes, atherosclerosis and the consequences of aging (17). The highest content of flavonoids was found in parsley extracts made from leaves (8). Numerous in vitro models have proven the high antioxidant capacity of different polarity extracts of leaves, aerial parts and roots, as well as the essential oil of the fruit. Parsley extracts (mostly methanol and aqueous), with apigenin as active compound, show a high capacity to neutralize 2,2-diphenyl-1-picrylhydrazyl (DPPH) radicals, high chelating capacity of $\mathrm{Fe}^{2+}$ ions, high ability to "capture" hydroxyl radicals and significant lipid peroxidation inhibition capacity in vitro. All these effects were higher than tested standards and are dosedependent $(9,10)$. The essential oil of the fruit, with myristicin and apiol as main compounds, also expresses antioxidant activity, but it is lower than the activity of the mentioned extracts and tested standard substances (24). Additionally, it is believed that sesquiterpenes play a potentially important role in the antioxidant effect of parsley essential oil (10). Various leaf extracts have shown antioxidative activity on isolated rat brain, liver and blood by increasing the activity of enzymes, such as glutathione peroxidase, xanthine oxidase and catalase, or by decreasing lipid peroxidation $(25,26)$.

The introduction of parsley leaves into the diet of 14 people ( 7 males and 7 females) for one week caused a significant increase in the levels of antioxidant enzymes, erythrocyte glutathione reductase and superoxide dismutase compared to the control group of people with a normal diet. Apigenin is the most responsible for this effect (27). 


\section{Anti-inflammatory effect}

An in vitro study of the anti-inflammatory effect of water-methanol extract of the parsley herb, rich in flavonoids and other polyphenols, was performed. All the effects of parsley extract correlated with the content of flavonoids, but not with the content of total polyphenols, which indicates the important role of flavonoids in the anti-inflammatory action. Parsley extracts have a high potential for removing nitric oxide (NO) free radicals, a strong antidenaturation effect on proteins, and a high potential for membrane stabilization, compared to diclofenac-sodium as a standard. There is evidence (experiments with $p$-lactoglobulin, bovine serum albumin and soybean glycine) that the interaction between flavonoids and protein increases the thermal stability of the protein and has a great influence on its secondary structure, which explains the antidenaturation effect. Flavonoids can build hydrogen bonds with the hydrophilic heads of the lipid bilayer of the membrane and thus reduce the fluidity and increase the rigidity of the membrane, which ensures its integrity and stabilization (28).

\section{Antibacterial effect}

Freeze-dried parsley leaves (in the quantities of 0.12 to $8 \%$ ) inhibit the growth of Escherichia coli, Listeria monocytogenes, L. innocua and Erwinia carotovora, while they are inefficient against Pseudomonas fragi. This effect can be related to the presence of furanocoumarins (1). Methanol and aqueous leaf and stem extracts have an antibacterial effect against Bacillus subtilis and E. coli. This effect is also due to the presence of furanocoumarins. Leaf extracts are more effective in terms of cell damage of both bacteria, while stem extracts have a stronger inhibitory effect on the growth of both bacteria (29). Methanol leaf extract also has in vitro antimicrobial activity against Pseudomonas aeruginosa, Staphylococcus epidermidis, S. aureus and Saccharomyces cerevisiae (30). Ethanol leaf extract inhibits the growth of Lactobacillus plantarum and Leuconostoc mesenteroides (9).

Essential oils have a greater in vitro and in vivo antibacterial potential than extracts, and they are generally more effective against G+ bacteria, since G- bacteria are less sensitive due to the specific composition of the cell membrane, which represents a barrier to hydrophobic substances such as essential oils $(10,11)$. Due to their complex composition, they probably act through several mechanisms of action simultaneously, such as cell wall lysis, increase of membrane permeability, consequent loss of ions, decrease of membrane potential, proton pump dysfunction and decrease of ATP reserves. Several studies have confirmed the effectiveness of essential oils against bacteria resistant to numerous antibiotics, and they are also effective in dermatological infections. Parsley essential oil from aerial parts demonstrated a moderate antibacterial effect, and was bactericidal against E. coli (minimal inhibitory concentration, MIC $32 \mathrm{mg} / \mathrm{mL}$ ) and Bacillus spisizeciaela (MIC $16 \mathrm{mg} / \mathrm{mL}$ ), and bacteriostatic against S. epidermidis (MIC $4 \mathrm{mg} / \mathrm{mL}$ ), S. aureus (MIC $16 \mathrm{mg} / \mathrm{mL}$ ), Enterococcus faecalis (MIC $16 \mathrm{mg} / \mathrm{mL}$ ) and Klebsiella pneumonia (MIC $32 \mathrm{mg} / \mathrm{mL}$ ), except against $P$. aeruginosa (11). 
High antibacterial activity of the essential oil phenolic components has been linked to the alkyl substitution of the phenolic nucleus, which rarely occurs with stable oil constituents such as myristicin, one of the main components of parsley essential oil. Monoterpene components have practically no antibacterial effect due to low solubility in water. It is important to note that several studies have shown that essential oil usually has a stronger antibacterial effect than a mixture of its main components, which indicates the importance of compounds present in smaller quantities (11).

\section{Hypolipidemic effect}

The hypolipidemic effect of $20 \%$ methanol extract of parsley fruit was proven in vivo in rats fed with a diet rich in fat and cholesterol. The 8-week administration of the mentioned parsley extract in hypercholesterolemic rats significantly decreased the total cholesterol, triglycerides, low density lipoprotein (LDL) cholesterol, very low density lipoprotein (VLDL) cholesterol and increased the level of high density lipoprotein (HDL) cholesterol in the blood. Also, biomarkers of heart and liver tissues were monitored in the study as well: the use of this extract decreases the levels of all enzymes: lactate dehydrogenase (LDH), creatine kinase-MB (CK-MB), ALT, AST and alkaline phosphatase (ALP). The examination of organs (liver, heart and blood vessels) with extract-treated rats showed an almost normal tissue structure with significantly milder damage compared to the organs of rats with hyperlipidemia. The hypolipidemic effect of parsley can be caused by the presence of plant proteins, betalaine, glucosinolates and antioxidant components, while the organoprotective effect is most likely due to the action of antioxidant ingredients such as flavonoids, carotenoids and phenolic compounds (18).

\section{Antihypertensive effect}

Examination of the antihypertensive effect of parsley aerial part aqueous extract was performed in vivo on rats with normal blood pressure and N-nitro-l-arginine methyl ether (L-NAME) induced hypertension, after a single application of parsley extract (acute treatment) and after repeated application of the same extract (sub-chronic treatment). After one dose of the aqueous extract, a decrease in systolic, diastolic and mean blood pressure was noted in hypertensive rats, while the effect was absent in normotensive rats. With repeated administration, there was a decrease in arterial blood pressure in both groups, with a stronger hypotensive effect in hypertensive individuals. In order to determine the mechanism of action, an in vitro study was performed on an isolated rat aorta. A pronounced dose-dependent vasodilatory effect on contractions induced by $\mathrm{KCl}$ and epinephrine was demonstrated, by blocking the entry of extracellular $\mathrm{Ca}^{2+}$ into smooth muscle cells of the aortic wall, through voltage-gated and receptor-operated $\mathrm{Ca}^{2+}$ channels. Parsley extract-induced vasorelaxant effect was endothelium-independent and was not mediated trough the potassium channels, $\beta$-adrenergic receptors, vascular cyclooxygenase or NO-cGMP pathways. The diuretic effect of parsley the most likely contributed to the antihypertensive effect. Interestingly, the potentiating effect of LNAME (NO synthase inhibitor) on the vasodilatory effect of low-dose parsley extract was 
observed in this study and requires further consideration (31). Aqueous and ethanol parsley leaf extract lowered blood pressure measured in the carotid artery of anesthetized rats; ethanol extract showed a stronger hypotensive effect. Reduced pulse strength and heart rate were observed in the subsequently isolated rat heart chamber, and this effect was more pronounced with ethanol extract. These results indicate antihypertensive and negative inotropic and chronotropic effects of parsley leaf extracts (9).

\section{Antidiabetic activity}

Antidiabetic effect of aqueous parsley leaf extract has been examined in several studies. It has been demonstrated that the extract lowers blood glucose levels and serum ALP and ALT, and has hepatoprotective and cardioprotective effects in rats with streptozotocin-induced diabetes. The antihyperglycemic effect is not due to the regeneration of pancreatic $\beta$-cells, since no morphological changes have been observed in the pancreas due to treatment with parsley leaf extract, but due to the presence of flavonoids, phenolic components and ascorbic acid and their antioxidant action (9).

\section{Effects on the gastrointestinal tract}

The ingredients of parsley essential oil stimulate the secretion of bile and gastric juices and thus contribute to better digestion (1). Ethanol leaf extract has beneficial effects on peptic ulcer in rats due to its antisecretory and cytoprotective effect; tannins, flavonoids and triterpenes are responsible for the effects (32). The aqueous extract from parsley seeds exhibited laxative activity in vivo by the inhibition of sodium and water absorption via colon $\mathrm{Na}^{+} / \mathrm{K}^{+}$- ATPase (33).

\section{Estrogenic activity}

In estrogen-dependent breast tumor cell line, methanol extract of the parsley aerial parts shows proliferative activity (estrogenic effect), similar to soybean isoflavone glycoside. This effect is primarily attributed to flavonoid glycoside 6"-acetylapiin, and aglycones apigenin, diosmetin and kaempferol. Additionally, oral administration of the extract can significantly restore uterine mass that is reduced after an ovariectomy performed in mice, and the effect is derived from apiin and apigenin $(1,15,34)$.

\section{Antiplatelet effect}

Aqueous parsley leaf extract in vitro shows a strong antiplatelet effect, with apigenin and cosmosin being responsible for this activity (35). Kaempferol and apigenin aglycones, previously incorporated into human platelets, reduce their adhesion to the collagen-coated surface and inhibit dose-dependent aggregation in various in vitro models (aggregation induced by ADP, collagen, thrombin) (36). In rats, aqueous extract administered orally inhibits platelet aggregation in vivo and significantly delays bleeding time ex vivo (37). 


\section{Other pharmacological and non-pharmacological effects}

In vitro studies have demonstrated the neuritogenic effect of falcarinol on paraneurons and the neuroprotective effect on induced neuronal apoptosis. In experiments on mice, scopolamine-induced memory deficits improved, which was thought to be a consequence of the aforementioned effects on neurons. Furthermore, falcarinol isolated from the root of Angelica sinensis acts by serotonin 5-HT7 receptors, which implies a potential serotonergic effect. Additional in vivo studies are necessary to determine whether falcarinol is a candidate for Alzheimer's disease treatment or for improvement in mood and behavior (12).

Isolated oil of parsley fruit showed a protective effect on the reproductive system in zearalenone-caused toxicity in in vivo studies. An increased level of testosterone, number and motility of sperm was determined. Moreover, inhibition of chromosomal aberrations of germ cells caused by zearalenone was detected (38). The hydroalcoholic extract of parsley fruit showed significant analgesic effects in some studies conducted on mice (e.g. a test based on formalin-induced paw licking; on the other hand, there was no significant results in a test based on acetic acid-induced cramping) (39). Parsley root deodorant effect is becoming more frequently recognized, especially in the context of neutralizing the odor of garlic (8).

Myristicin caused the inhibition of benz[a]pyrene-induced tumor development in studies on mice, possibly due to the stimulation of glutathione-S-transferase synthesis in liver and small intestine mucosa (1). Myristicin demonstrated hepatoprotective and anxiolytic effects in rats, and also insecticidal and anti-inflammatory activity. Additionally, myristicin metabolite named MMDA (3-methoxy-4,5methylenedioxyamphetamine) acts as a monoamine oxidase inhibitor and agonist of serotonin receptor. It was reported that apiol can cause antipyretic, insecticidal, diuretic and antitumor effects (5). Essential oil acted as an immunosuppressant in in vivo studies. It caused the inhibition of splenocyte and macrophage (as major congenital immune cells) function, which led to a decrease in humoral and cellular immune response. Also, in higher concentrations, parsley essential oil suppressed the production of NO (40). An in vitro study on hamster lung fibroblasts, thyroid epithelial cells of rats and astrocytes isolated from neonatal mice has been conducted. In this study, geraldol (isolated from parsley) inhibited binding of NMO-IgG autoantibodies, which are present at $80 \%$ of NMO (neuromyelitis optica) patients, for aquaporin-4 (AQP4 - the most common water transport channel in astrocytes membrane) without affecting the physiological function of these channels (41).

\section{Toxicity and side effects}

After the ingestion of a regular amount of parsley leaf and root (as a spice), acute and chronic poisoning was not observed. Parsley fruit has never been used as a spice, because of phenylpropane derivatives which are toxic in high levels (1). Side effects were not detected after medical use of therapeutic dosages of parsley herb and root (7). Parsley 
has a low potential of sensibilization, but allergic reactions are possible and could be the consequence of contact with fresh plant, herbal drug or essential oil $(1,6,7)$. Most frequently, they occur among people who are allergic to other plants from the Apiaceae family (e.g. celery, carrots and caraway) and among light-skinned people. Additionally, photodermatosis occurs in commonly exposed people (e.g. garden workers) after intensive contact with the fresh plant $(1,7)$. Furanocoumarins (such as oxypeucedanin) and polyacetylenes (such as falcarinol) are responsible for this effect, but their levels in parsley are low, and desensitization may also occur after oral ingestion $(1,6,9,12,42)$.

The application of higher doses of the essential oil or products that contain high concentrations of the essential oil can cause poisoning. Symptoms include increased smooth muscle contractility, specifically in the bladder, intestine and uterus, also anuria, blood in the stool, general weakness, steatosis, hemolysis, methaemoglobinuria and bleeding of mucous membranes (7). Myristicin (0.01-0.05 mL/L), apiol (50-100 mg/L) and fruit essential oil abortifacient effect has been shown in some previous studies. This effect appears as a result of increased tonus and contractions in isolated guinea pig uterus. Essential oil leads to acute toxicity in high abortus-used doses by causing gastroenteritis, headache, kidney and liver damage, coma and death (1). Pure apiol in higher doses has abortifacient effect. Based on the available evidence, damage of liver parenchyma and heart arrhythmias were detected after an apiol overdose. However, it should be noted that all these effects were observed after the use of high doses of the essential oil (concentrated plant isolate) or pure isolated compounds, while there is no danger of intoxication after common use of parsley (8). Myristicin poses a hallucinogenic effect (contributed to his metabolite MMDA). Consequently, after ingestion of larger amounts of the essential oil, central excitation was noticed; drunkenness, strong irritations of gastrointestinal and urinary tract are also possible $(5,8)$. Apiol and myristicin demonstrated hepatocarcinogenic effects (6).

\section{The use of parsley in folk medicine}

Parsley roots are useful for dysmenorrhea, nocturia in kids and as a stomachic $(6,8)$. Parsley roots and herb are used for gastrointestinal problems, jaundice, kidney inflammation, as a diuretic and emmenagogues in treatment of menstrual problems and flatulence $(1,7)$. The spasmolytic effect of parsley fruit can help with dysmenorrhea and menstrual cramps. Additionally, parsley fruit acts as an emmenagogues, galactagogue, stomachic and digestive, and it has also proven useful in relation to the disrupted function of kidneys and lower urinary tract $(7,8)$.

The use of parsley in folk medicine differs across the countries (9). In Serbia, parsley leaf is used as a diuretic, in the treatment of infections and diseases of the urinary system and in the treatment of fluid retention in the organism $(43,44)$. In Iranian folk medicine, parsley is used as a carminative, astringent, gastrotonic, antidote, as well as for kidney stones, inflammation, amenorrhoea, halitosis and for improvement of digestion. Parsley leaf is known as a spice, diuretic and antitussive; additionally, the leaf can be significant in the treatment of dermatitis, vision problems, otitis etc. (9). In different 
countries such as Spain, Italy, Turkey, China, Iraq, Morocco and Peru, parsley is used for various purposes. It is thought that the leaf acts as a disinfectant, anticoagulant, antihypertensive, antihyperlipidemic, abortifacient. Also, the leaf showed beneficial effects in diabetes, cardiac and renal diseases, kidney stones, abdominal aches, hyperuricaemia, skin disease, lumbago, eczema, problems with appetite, nose bleeding, insect bites, anaemia, constipation, baldness, odontalgy, amenorrhea and dysmenorrhea $(5,9)$. Aerial parts of parsley are used as abortifacients, while seeds are used as a carminative and in the treatment of gastritis (9).

\section{Traditional use of parsley}

Parsley roots and essential oil are used as a diuretic in urinary tract disease, as well as for irrigation for prevention or treatment of urinary stones. Contrary to herbal teas or herbal medicinal products, the essential oil is rarely used for therapeutic purposes (6). Parsley roots and herb are used for infections of the urinary tract and for kidney stones. Homeopathic preparations of parsley roots and herb are used for inflammation of the urinary tract and for sensitive bladder (7).

\section{Modern-day use of parsley}

Parsley is known as an antioxidant and anti-inflammatory agent-rich plant (the leaves contain significant levels of polyphenols and flavonoids). Various possible therapeutic indications for parsley use could be based on these effects $(23,28)$. Parsley represent a natural safe remedy which could be used as an anti-inflammatory (reduces inflammation, especially in joints), antihyperglycemic (decreases glucose level in blood of diabetes induced rats), antihyperlipidemic (by enhancing serum lipid profile), antihypertensive (diuretic effect also contributes to blood pressure lowering), hypouricemic (high level of antioxidative substances contributes to the reduction of hyperuricemia and gout effect on liver, kidney and other tissues) and antimicrobial agent $(18,19,23,31)$. Additionally, hepatoprotective and cardioprotective effect, reduction of allergy symptoms, chronic bronchitis, skin diseases, cystitis, thrombosis, stroke and Alzheimer's disease are promising, but human studies are still missing $(9,13,18,23)$.

\section{Contraindications}

Parsley herbal drug-based preparations are contraindicated when used by people allergic to parsley or apiol. People with renal inflammatory disease may not use the herb and roots of parsley, as well as people with edema caused by insufficient heart or renal function when used as irrigation treatment. Also, in pregnant women, the use of herb, roots and fruit is contraindicated because of the abortive effect of parsley $(1,7,8)$.

\section{Conclusion}

Parsley is an edible plant with positive effects on human health. Based on morphological characteristics, parsley is a classic representative of Apiaceae family, with fruit schizocarp rich in essential oil. Petroselinum crispum ssp. foliosum is generally 
richer in essential oil in comparison to $P$. crispum ssp. tuberosum. In the parsley fruit, the most common essential oil substances are phenylpropanoids. Apiol, myristicin and 1allyl-2,3,4,5-tetramethoxybenzene were detected in the highest level. The chemical composition of essential oil differs between parsley parts and varieties, geographical location of cultivation, development stage of plant, seasonal variations, climatic conditions, genetic and other factors. In most cases, the main compound of the flat leaf form of parsley is apiol, and of the curly leaf form - myristicin. The essential oil of parsley roots is rich in monoterpenes, in essential oil of $P$. crispum ssp. foliosum roots terpinolene dominates, and in $P$. crispum ssp. radicosum $\beta$-pinene. Polyacetylenes are the main ingredients of $P$. crispum ssp. tuberosum roots. Flavonoids are the predominant compounds of parsley leaves (up to 3 times more in comparison to parsley fruit and roots). Apiin is considered the most important flavonoid detected. Oxypeucedanin, psoralen, bergaptene, xanthotoxin, imperatorin and isopimpinellin are relevant representatives of furanocoumarins. Parsley leaf is a significant source of minerals and vitamins.

Parsley fruit, root, leaf and essential oil showed diuretic, spasmolytic and antiurolytic activity. Parsley leaf-based preparations demonstrated hypouricemic and, also antioxidative, anti-inflammatory, antibacterial, estrogenic, hypoglycemic, hypotensive and antiagregative effects in experiments, while fruit extract acted as a hypolipidemic, laxative and analgesic. Studies have indicated the importance of sesquiterpenes, as well as other substances that were present in lower concentrations, for the antioxidative effect of essential oil, while the weakening of antibacterial effect was also in correlation with the increased content of myristicin in the essential oil.

Apiol and myristicin showed insecticidal and antitumor effects, while flavonoids were the carriers of antioxidative and anti-inflammatory activity of parsley. Falcarinol could be characterized as a cardio protective and a candidate for treatment of Alzheimer's disease, mood and behavior disorders, but further in vivo research is needed.

Allergic reactions manifested as photodermatosis are very rare. Adverse effects after the ingestion of therapeutic doses were not recorded, which qualifies this plant and its pharmacologically active compounds for further in vivo research and research on human subjects, in order to fulfill its therapeutic potential.

\section{References}

1. Teuscher E, Bauermann U, Werner M. Medicinal spices: A Handbook of Culinary Herbs, Spices, Spice Mixtures and Their Essential Oils. Florida: Medpharm Scientific Publishers, Stuttgart, CRC Press, Taylor and Francis Group; 2006. 460 p.

2. Evans WC. Trease and Evans Pharmacognosy. 16th ed. Saunders Elsevier; 2009. 603 p.

3. Nikolić V. Familija Apiaceae L. In: Josifović M, editor. Flora SR Srbije V. Beograd: Srpska akademija nauka i umetnosti; 1973; p. 183-9.

4. Jančić R, Lakušić B. Botanika farmaceutika, 6th ed. Beograd: Lento; 2017. 293 p. 
5. Craft JD, Setzer WN. The volatile components of parsley, Petroselinum crispum (Mill.) Fuss. Am J Essent Oil Nat Prod. 2017;5(1):27-32.

6. Kovačević N. Osnovi farmakognozije, 3rd ed. Beograd: Srpska školska knjiga; 2004. 408 p.

7. Heber D. PDR for Herbal Medicines, 4th ed. Thomson Healthcare Inc.; 2007. 1026 p.

8. Wichtl M. Teedrogen und Phytopharmaka Ein Handbuch fur die Praxis auf wissenschaftlicher Grundlage. 4th ed. Stuttgart: Wissenschaftliche Verlagsgesellschaft; 2002. 441-8 p.

9. Farzaei MH, Abbasabadi Z, Ardekani MRS, Rahimi R, Farzaei F. Parsley: a review of ethnopharmacology, phytochemistry and biological activities. J Tradit Chin Med. 2013;33(6):815-26.

10. Marín I, Sayas-Barberá E, Viuda-Martos M, Navarro C, Sendra E. Chemical Composition, Antioxidant and Antimicrobial Activity of Essential Oils from Organic Fennel, Parsley, and Lavender from Spain. Foods. 2016;5:18.

11. Jugreeta BS, Mahomoodally MF. Essential oils from 9 exotic and endemic medicinal plants from Mauritius shows in vitro antibacterial and antibiotic potentiating activities. S Afr J Bot. 2020;132:355-62.

12. Christensen LP. Aliphatic C17-Polyacetylenes of the Falcarinol Type as Potential Health Promoting Compounds in Food Plants of the Apiaceae Family. Recent Pat Food Nutr Agric. 2011;3:64-77.

13. Fernandes A, Polyzos N, Petropoulos SA, Pinela J, Ardohain E, Moreira G et al. Phytochemical Composition and Nutritional Value of Pot-Grown Turnip-Rooted and Plain and Curly-Leafed Parsley Cultivars. Agronomy. 2020;10:1416-15.

14. Al-Yousofy F, Gumaih H, Ibrahim H, Alasbahy A. Parsley! Mechanism as antiurolithiasis remedy. Am J Clin Exp Urol. 2017;5(3):55-62.

15. Hozayen, WG, El-Desouky MA, Soliman HA, Ahmed RR, Khaliefa AK. Antiosteoporotic effect of Petroselinum crispum, Ocimum basilicum and Cichorium intybus L. in glucocorticoid-induced osteoporosis in rats. BMC Comp Alt Med. 2016;16:165.

16. Nirumand MC, Hajialyani M, Rahimi R, Farzaei MH, Zingue S, Nabavi SM et al. Dietary Plants for the Prevention and Management of Kidney Stones: Preclinical and Clinical Evidence and Molecular Mechanisms. Int J Mol Sci. 2018;19:765.

17. Epifanio NMM, Cavalcanti LRI, Santos KF, Duarte PSC, Kachlicki P, Ożarowski M et al. Chemical characterization and in vivo antioxidant activity of parsley (Petroselinum crispum) aqueous extract. Food Funct. 2020;11:5346-56.

18. El Rabey HA, Al-Seeni MN, Al-Ghamdi HB. Comparison between the Hypolipidemic Activity of Parsley and Carob in Hypercholesterolemic Male Rats. BioMed Res Int. doi: 10.1155/2017/3098745.

19. Kreydiyyeh SI, Usta J. Diuretic effect and mechanism of action of parsley. J Ethnopharmacol. 2002;79:353-7.

20. Alexander SPH. Flavonoids as antagonists at $A_{1}$ adenosine receptors. Phytother Res. 2006;20:1009-12.

21. Moazedi AA, Mirzaie DN, Seyyednejad SM, Zadkarami MR, Amirzargar A. Spasmolytic effect of Petroselinum crispum (Parsley) on rat's ileum at different calcium chloride concentrations. Pak J Biol Sci. 2007;10(22):4036-42.

22. Branković S, Kitić D, Radenković M, Ivetić V, Veljković S, Nešić M. Relaxant activity of aqueous and ethanol extracts of parsley (Petroselinum crispum (Mill) Nym. ex A. W Hill, Apiaceae) on isolated ileum of rat. Med Pregl. 2010;63(7-8):475-8. 
23. Soliman MM, Nassan MA, Aldhahrani A, Althobaiti F, Mohamed WA. Molecular and Histopathological Study on the Ameliorative Impacts of Petroselinum crispum and Apium graveolens against Experimental Hyperuricemia. Sci Rep. 2020;10:9512.

24. Zhang H, Chen F, Wang X, Yao HY. Evaluation of antioxidant activity of parsley (Petroselinum crispum) essential oil and identification of its antioxidant constituents. Food Res Int. 2006;39(8):833-9.

25. Popović M., Kaurinović B, Jakovljević V, Mimica-Dukic N, Bursać M. Effect of parsley (Petroselinum crispum (Mill.) Nym. ex A.W. Hill, Apiaceae) extracts on some biochemical parameters of oxidative stress in mice treated with $\mathrm{CCl}_{4}$. Phytother Res. 2007;21:717-23.

26. Fejes S, Blázovics A, Lemberkovics E, Petri G, Szoke E, Kéry A. Free radical scavenging and membrane protective effects of methanol extracts from Anthriscus cerefolium L. (Hoffm.) and Petroselinum crispum (Mill.) nym. ex A.W. Hill. Phytother Res. 2000;14(5):362-5.

27. Nielsen SE, Young JF, Daneshvar B, Lauridsen ST, Knuthsen P, Sandström B et al. Effect of parsley (Petroselinum crispum) intake on urinary apigenin excretion, blood antioxidant enzymes and biomarkers for oxidative stress in human subjects. Br J Nutr. 1999;81(6):447-55.

28. Derouicha M, Bouhlali EDT, Hmidani A, Bammouc M, Bourkhis B, Sellamc K et al. Assessment of total polyphenols, flavonoids and anti-inflammatory potential of three Apiaceae species grown in the Southeast of Morocco. Sci Afr. 2020;9:e00507.

29. Wong PYY, Kitts DD. Studies on the dual antioxidant and antibacterial properties of parsley (Petroselinum crispum) and cilantro (Coriandrum sativum) extracts. Food Chem. 2006;97(3):505-15.

30. Ojala T, Remes S, Haansuu P, Vuorela H, Hiltunen R, Haahtela K et al. Antimicrobial activity of some coumarin containing herbal plants growing in Finland. J Ethnopharmacol. 2000;73(1-2):299-305.

31. Ajebli M, Eddouks M. Antihypertensive activity of Petroselinum crispum through inhibition of vascular calcium channels in rats. J Ethnopharmacol. 2019;242:112039.

32. Al-Howiriny T, Al-Sohaibani M, El-Tahir K, Rafatullah S. Prevention of experimentally-induced gastric ulcers in rats by an ethanolic extract of "Parsley" Petroselinum crispum. Am J Chin Med. 2003;31(5):699-711.

33. Kreydiyyeh SI, Usta J, Kaouk I, Sadi RA. The mechanism underlying the laxative properties of Parsley extract. Phytomedicine. 2001;8(5):382-8.

34. Yoshikawa M, Uemura T, Shimoda H, Kishi A, Kawahara Y, Matsuda H. Medicinal foodstuffs. XVIII. Phytoestrogens from the aerial part of Petroselinum crispum MIll. (Parsley) and structures of 6"-acetylapiin and a new monoterpene glycoside, petroside. Chem Pharm Bull (Tokyo). 2000;48(7):1039-44.

35. Chaves DS, Frattani FS, Assafim M, de Almeida AP, de Zingali RB, Costa SS.. Phenolic chemical composition of Petroselinum crispum extract and its effect on haemostasis. Nat Prod Commun. 2011;6(7):961-4.

36. Gadi D, Bnouham M, Aziz M, Ziyyat A, Legssyer A, Bruel A et al. Flavonoids purified from parsley inhibit human blood platelet aggregation and adhesion to collagen under flow. J Complement Integr Med. 2012;9:Article 19.

37. Gadi D, Bnouham M, Aziz M, Ziyyat A, Legssyer A, Legrand C et al. Parsley extract inhibits in vitro and ex vivo platelet aggregation and prolongs bleeding time in rats. J Ethnopharmacol. 2009;125(1):170-4. 
38. Abdel-Wahhab MA, Abbes S, Salah-Abbes JB, Hassan AM, Oueslati R. Parsley oil protects against Zearalenone-induced alteration in reproductive function in male mice. Toxicol Lett. 2006;164:S266.

39. Behtash N, Kargarzadeh F, Shafaroudi H. Analgesic effects of seed extract from Petroselinum crispum (Tagetes minuta) in animal models. Toxicol Lett. 2008;180(Suppl5):S127-S128.

40. Yousofi A, Daneshmandi S, Soleimani N, Bagheri K, Karimi MH. Immunomodulatory effect of Parsley (Petroselinum crispum) essential oil on immune cells: mitogen-activated splenocytes and peritoneal macrophages. Immunopharmacol Immunotoxicol. 2012;34(2):303-8.

41. Wang J, Wang S, Sun M, Xu H, Liu W, Wang D et al. Identification of geraldol as an inhibitor of aquaporin-4 binding by NMO-IgG. Mol Med Rep. 2020;22:1111-18.

42. Peroutka R, Schulzová V, Botek P, Hajšlová J. Analysis of furanocoumarins in vegetables (Apiaceae) and citrus fruits (Rutaceae). J Sci Food Agric. 2007;87(11):2152-63.

43. Tucakov J. Lečenje biljem, 2nd ed. Beograd: Rad; 1984. 735 p.

44. Šavikin K, Zdunić G, Menković N, Živković J, Ćujić N, Tereščenko M et al. Ethnobotanical study on traditional use of medicinal plants in South-Western Serbia, Zlatibor district. J Ethnopharmacol. 2013;146 (3):803-10. 


\title{
Pregled botaničkih karakteristika, hemijskog sastava, farmakološke aktivnosti i primene peršuna
}

\author{
Milka Punoševac, Jelena Radović, Aleksandra Leković, \\ Tatjana Kundaković-Vasović
}

Univerzitet u Beogradu - Farmaceutski fakultet, Katedra za farmakognoziju, Vojvode Stepe 450, 11221 Beograd, Srbija

*Autor za korespondenciju: Tatjana Kundaković-Vasović, e-mail: ktatjana@pharmacy.bg.ac.rs

\section{Kratak sadržaj}

Peršun je dvogodišnja aromatična biljka iz familije Apiaceae koju karakterišu nerazgranat koren, perasto deljeni listovi, štitaste cvasti i plod šizokarpijum. U svim delovima sadrži etarsko ulje, čije su glavne komponente fenilpropanska i terpenska jedinjenja. Bogat je flavonoidima i drugim polifenolnim jedinjenjima, sadrži furanokumarine, karotenoide, poliacetilene, a listovi su izvor vitamina i minerala. Hemijski sastav peršuna zavisi od brojnih faktora, pa tako postoje razlike u sastavu između ne samo različitih delova i varijeteta biljke, već i različitih uzoraka istih delova jednog varijeteta. Najzastupljenija jedinjenja peršuna su miristicin, apiol, 1-alil-2,3,4,5tetrametoksibenzen, $\beta$-felandren, 1,3,8- $p$-mentatrien, $\beta$-pinen, terpinolen, apiin, oksipeucedanin i falkarinol. Peršun ima dugu tradiciju upotrebe $u$ tretmanu poremećaja funkcije urinarnog trakta, a savremena in vitro i in vivo ispitivanja otkrivaju i brojne efekte koje poseduju različiti preparati peršuna kao što su diuretički, antiurolitijazni, hipourikemijski, hipolipidemijski, hipoglikemijski, hipotenzivni, antioksidativni, antiinflamatorni, antimikrobni i antiagregacioni. Danas, pored medicinske primene, peršun je jedna od najkorišćenijih začinskih biljaka.

Ključne reči: Petroselinum crispum, etarsko ulje, flavonoidi, antioksidansi 